\title{
Multidimensional Analysis Associated With Growth Analysis in the Selection of Organic Substrates for the Production of Tomato Seedlings
}

\author{
Deoclecio Jardim Amorim ${ }^{1}$, Jania Claudia Camilo dos Santos ${ }^{1}$, Luisa Julieth Parra-Serrano ${ }^{2}$, \\ Maryzélia Furtado de Farias ${ }^{2} \&$ Marileia Barros Furtado ${ }^{2}$ \\ ${ }^{1}$ State University of São Paulo, Júlio de Mesquita Filho, Botucatu, Brazil \\ ${ }^{2}$ Federal University of Maranhão, Chapadinha, Brazil \\ Correspondence: Luisa Julieth Parra-Serrano, Federal University of Maranhão, CCAA-UFMA, MA-230, km 04, \\ s/n, Boa Vista, 65500-000, Chapadinha, Maranhão, Brazil. Tel: 55-98-3471-1201. E-mail: julieth_ps@yahoo.com
}

Received: July 24, $2018 \quad$ Accepted: August 26, $2018 \quad$ Online Published: October 15, 2018

doi:10.5539/jas.v10n11p326 URL: https://doi.org/10.5539/jas.v10n11p326

\begin{abstract}
Tomato (Solanum lycopersicum L.) is a crop whose cultivation is of great importance in economic and social aspects. However, the development of efficient and low-cost technologies is essential for the growth of agricultural activity in the region. Among the most studied technologies, the production of quality seedlings in organic substrates is highlighted. In this context, the objective was to evaluate the development of tomato seedlings produced with organic substrates, using the decomposed stem of babassu palm and goat manure, using the multidimensional technique with the help of canonical functions associated with growth analysis. The treatments consisted of $25 \%, 50 \%$ and $75 \%$ sand aggregates, $25 \%$ to $50 \%$ sand addition, $25 \%$ to $50 \%$ sand and commercial substrate, established in a completely randomized design with 28 treatments and four replications in a $7 \times 4$ factorial scheme, the first factor consisting of seven substrates and the second of four evaluation periods ( $7,14,21,28$ days after emergence). Were analyzed shoot length and main root length; dry mass of the aerial part and of the root system and leaf area. These variables were analyzed through multidimensional analysis with the help of canonical functions and growth analysis. In general, the substrates consisting of goat manure and sand were superior to the substrates consisting of the decomposed palm tree stem and the commercial substrate. The alternative substrate formed by the mixture of goat manure, in the proportion of $25 \%$ of sterilized sand + $75 \%$ goat manure, constitutes the best option for the production of tomato seedlings.
\end{abstract}

Keywords: Solanum lycopersicum L., babassu, substrates, organic materials

\section{Introduction}

The tomato (Solanum lycopersicum L.) is the main representative culture of the family Solanaceae, whose cultivation has great importance, in the economic and social aspects. In 2017, the Brazilian production of tomatoes increased by $4.9 \%$ in relation to 2016 , obtaining a production of 4.3 million tons, approximately 64.6 thousand hectares, accounting for about 5.34 billion reais of the gross value of Brazilian agricultural production (IBGE, 2017).

In the Northeast, the states of Bahia, Pernambuco and Ceará account for more than $90 \%$ of tomato production, while other states, such as Maranhão, account for less than 1\% of regional production (IBGE, 2018). The low representation of the state of Maranhão in the regional and national tomato culture is mainly due to the lack of investments, in the majority of agricultural properties, and the low technological level of the producers. In face of this problem, there is a need for the development of efficient and low-cost technologies in the region.

Among the technologies most studied, it is worth mentioning the production of quality seedlings, which is based on researches with better combinations of substrates, using two or more materials. In the production of seedlings, organic, mineral and synthetic materials, pure or in mixtures, are used to meet the requirements of each species (Costa et al., 2015). In the last years, the research has converged to the study of organic materials and its local availability, which seeks to reduce costs (Lima et al., 2011; Souza et al., 2013).

From the economic and agronomic point of view, the organic materials most used in the formulation of substrates are manures and fibers. The great use of manure is mainly due to availability and low cost, which has led producers to consider organic fertilization as a viable alternative (Alencar et al., 2008). The main fiber used 
in the composition of substrates is coconut (Cocos nucifera L.) (Melo et al., 2012; Castoldi et al., 2014). However, the decomposed palm stem is another material used that presents satisfactory results (Albano et al., 2014).

It is worth mentioning that in addition to considering the availability of organic materials, the substrates must be of high quality, with physical / chemical properties that provide water, oxygen and nutrients to achieve optimal germination and growth of the seedlings and allowing the production of vigorous trees (Costa et al., 2009).

However, when it is desired to evaluate the quality of the substrates for seedling production, a large number of agronomic traits are taken into over time which frequently have a high negative or positive correlation, which makes it difficult to choose the best substrate for analysis one-dimensional. In this sense, the multidimensional technique with the help of canonical functions and growth analysis, appear as an alternative to this problem.

The multidimensional technique with the help of canonical functions reduces the dimensionality of the data for a single variable, making the choices more robust (Pimentel Gomes, 2002; Cabral et al., 2011). While the growth analysis contributes to the understanding of the morphophysiological conditions of the plants developed in each substrate and quantifies the net production, derived from the photosynthetic process during a certain period of time (Benincasa, 2004; Lopes et al., 2011).

Information in the literature that reports the use of goat manure and babassu palm decomposition stem (Attalea speciosa Mart.) As organic materials for the production of tomato seedlings in Maranhão are still scarce. In view of the above, the objective was to evaluate the development of Solanum lycopersicum seedlings produced with organic substrates, using the decomposed stem of babassu palm and goat manure, using the multidimensional technique with the help of canonical functions associated with growth analysis.

\section{Material and Methods}

\subsection{Collection of Samples}

The research was developed at the Center for Agrarian and Environmental Sciences of the Federal University of Maranhão, located in the city of Chapadinha in East Maranhense Mesoregion and Microregion of Chapadinha, in the state of Maranhão, located at $03^{\circ} 44^{\prime} 30^{\prime \prime}$ South of latitude and $43^{\circ} 21^{\prime} 33^{\prime \prime}$ West of longitude, with $105 \mathrm{~m}$ altitude (Gaspar et al., 2018). The climate of the municipality according to Köppen's climatic classification is Aw type, considered tropical zone with dry winter (Alvares et al., 2013). The experiment was conducted in a greenhouse with 50\% shading, using the tomato cultivar Santa Cruz Kada Gigante, from February to March, 2016.

\subsection{Implantation of the Experiment and Treatments Used}

The experiment was implanted following a completely randomized design, with 28 treatments and four replications, with each replicate consisting of 12 plants. The formation of the seedlings was carried out in trays of expanded polystyrene (Isopor ${ }^{\circledR}$ ). Each tray had 128 cells with a volume of $40 \mathrm{~cm}^{3}$.

The 28 treatments were arranged in factorial scheme $7 \times 4$; (S1-25\% sterilized sand $+75 \%$ decomposed palm stem, S2-50\% sterilized sand $+50 \%$ decomposed palm stem, S3-75\% sterilized sand $+25 \%$ decomposed palm stem, S4-25\% sterile sand $+75 \%$ goat manure, S5-50\% sterile sand $+50 \%$ goat manure, S6-75\% sterile sand + 25\% manure goat and S7-commercial substrate (Tropstrato $\mathrm{HT}^{\circledR}$ )) and the second factor constituted by four epochs of evaluation, being these realized every seven days. The proportions of sand, decomposed palm stem and goat manure were established on a volume basis.

\subsection{Description of the Materials Used in the Composition of the Substrates}

The commercial substrate Tropstrato HT®, according to the manufacturer, consists of: pine bark, vermiculite, PG Mix 14.16.18, potassium nitrate, simple superphosphate and peat. On the other hand, the alternative substrates were composed of a decomposed palm stem with sand addition in 25, 50 and 75\%, addition of goat manure in 25, 50 and $75 \%$ of goat manure sand and palm decomposed stem in proportions of 25,50 and $75 \%$. Table 1 shows the chemical physical analysis of the materials used to compose the substrates except for sand, since it is an inert material. 
Table 1. Chemical physical analysis of the materials used to compose the substrates

\begin{tabular}{lllllllll}
\hline \multirow{2}{*}{ Materials } & \multicolumn{9}{c}{ Variables } \\
\cline { 2 - 9 } & $\mathrm{pH}$ & $\mathrm{N}$ & $\mathrm{P}$ & $\mathrm{K}$ & $\mathrm{Ca}$ & $\mathrm{Mg}$ & $\mathrm{D}$ & $\mathrm{Po}$ \\
\hline \multirow{2}{*}{ Commercial substrate } & - & $\mathrm{g} \mathrm{kg}^{-1}$ & $\mathrm{mg} \mathrm{kg}^{-1}$ & $---------\mathrm{cmol}_{\mathrm{c}} \cdot \mathrm{kg}^{-1}----------$ & $\mathrm{g} \mathrm{cm}^{-3}$ & $\%$ \\
Decomposed palm stem & 7.58 & 7.10 & - & 0.45 & 0.10 & 0.10 & 0.34 & 83.51 \\
Goat manure & 5.32 & 5.88 & 33.00 & 3.63 & 20.60 & 15.20 & 0.33 & 65.95 \\
\hline
\end{tabular}

Note. Potential of hydrogen $(\mathrm{pH})$; nitrogen $(\mathrm{N})$; phosphor $(\mathrm{P})$; potassium $(\mathrm{K})$; calcium $(\mathrm{Ca})$; magnesium $(\mathrm{mg})$; density (D) and porosity (Po). Adapted from Maeda et al. (2007); Ludwig et al. (2010) and Oliveira Neto et al. (2018).

\subsection{Performed Analyzes}

The tomato cultivar Santa Cruz Kada Gigante (S. lycopersicum) was sown using three seeds per cell, thinning after germination. The plants were evaluated at 7, 14, 21 and 28 days after emergence. The evaluated indicators were: aerial part length (APL), cm; length of main root (LMR), cm; dry mass of the aerial part (DMAP), $\mathrm{g} \mathrm{plant}^{-1}$, and of the root system (MRS), $\mathrm{g}_{\text {plant }}{ }^{-1}$; and leaf area (LA), $\mathrm{cm}^{2}$.

The aerial and root dry masses were obtained after drying in an oven with forced air circulation at $60{ }^{\circ} \mathrm{C}$ for 72 hours, weighing in an electronic analytical balance $(0.001 \mathrm{~g})$. The leaf area was obtained by digital image of the leaves and processed by Image ${ }^{\circledR}$ software (Schneider et al., 2012).

\subsection{Statistical Analyzes}

The data of the variables APL, LMR, DMAP, MRS and LA were submitted to analysis of normality of residues required by the multidimensional analysis of variance denominated of Manova, using the generalized Shapiro Wilk test for multivariate distributions (Royston, 1982) that was implemented in the R software (R Development Core Team, 2018). Once the condition of residual normality was verified, a multidimensional analysis was performed by PROC GLM (SAS, 2002), using the Wilks test at 5\% probability, according to Pimentel Gomes (2002) to test the null hypothesis $\mathrm{H}_{0}$ that mentions the equality between vectors of means of the treatments. As the hypothesis was rejected by the Wilks test, the mean vectors of the treatments were analyzed statistically using the canonical functions.

The coefficients of the canonical functions, b1, b2, b3, b4 and b5, were obtained by analyzing the multidimensional analysis of the variables APL, LMR, DMAP, MRS and LA, generating the following linear function:

$$
Z=b 1 A P L+b 2 L M R+b 3 D M A P+b 4 M R S+b 5 L A
$$

This function was applied to the data of each experimental plot generating " $n$ " values of this unique variable $Z$, one of each " $n$ " plot of the experiment. Subsequently, the one-dimensional traditional variance analysis was applied to this new $\mathrm{Z}$ variable. Treatment averages were compared by the Scheffé test at $5 \%$ probability, as recommended by Pimentel Gomes (2002).

To obtain the physiological parameters of the growth analysis, such as growth rate of cultivation (GRC), relative growth rate (RGR), net assimilation rate (NAR) and leaf area ratio (LAR), leaf area and dry mass total of the plants were adjusted in relation to the time, by the ANACRES software (Portes \& Castro Junior, 1991), using quadratic exponential equations. The physiological parameters do not obey the basic assumptions of analysis of variance because they follow calculated data. In this way, the results were presented through graphs made by SigmaPlot $11.0^{\circledR}$ software, evaluating the behavior of the curves.

\section{Results and Discussion}

\subsection{Statistical Assumptions}

Based on the Pearson correlation analysis, significant correlations were found between the five variables analyzed (Table 2). These data are used to determine the differences that would not be found in analyzes of individual variances and would compromise the results, as demonstrated by Neto et al. (2007), in which the authors could not observe through univariated analyzes, significant effect of the main factors or the interaction. 
Table 2. Pearson correlations (r) of the variables: shoot length (APL); length of the main root (LMR); dry shoot mass (DMAP); dry mass of the root system (MRS) and leaf area (LA) in Solanum lycopersicum seedlings

\begin{tabular}{lllll}
\hline Variables 1 & Variables 2 & $\mathrm{n}$ & $\mathrm{r}$ & Significance of $\mathrm{r}$ \\
\hline APL & LMR & 112 & 0.40 & $<0.0001^{* *}$ \\
APL & MRS & 112 & 0.89 & $<0.0001^{* *}$ \\
APL & DMAP & 112 & 0.93 & $<0.0001^{* *}$ \\
APL & LA & 112 & 0.94 & $<0.0001^{* *}$ \\
\hline LMR & MRS & 112 & 0.56 & $<0.0001^{* *}$ \\
LMR & DMAP & 112 & 0.47 & $<0.0001^{* *}$ \\
LMR & LA & 112 & 0.50 & $<0.0001^{* *}$ \\
\hline MRS & DMAP & 112 & 0.95 & $<0.0001^{* *}$ \\
MRS & LA & 112 & 0.94 & $<0.0001^{* *}$ \\
DMAP & LA & 112 & 0.96 & $<0.0001^{* *}$ \\
\hline
\end{tabular}

Note. ${ }^{* *}$ All Pearson correlation coefficients were significant at 0.01 probability.

The Shapiro Wilk test generalized for multivariate distributions, revealed that Manova residues were distributed as a multivariate normal. A significant interaction effect was observed by the Wilks test for the vectors of treatment averages and times of evaluation at $5 \%$ of probability, showing the existence of at least one vector that differed from the others.

\subsection{Canonical Functions}

The use of canonical variables was feasible in this research, since it allowed the reduction of the dimensionality of the data set with the minimum loss of information. The first two variables added accounted for more than $92 \%$ of the treatments, being $85.6 \%$ for the first (ratio $\lambda_{1}$ ) and $6.5 \%$ for the second (ratio $\lambda_{2}$ ) (Table 3 ). Cabral et al. (2011) observed that the first two canonical variables explained approximately $82 \%$ of the total variation. Already Gonçalves et al. (2009), working with $S$. lycopersicum, verified that the first two canonical variables explained about $90 \%$ of the variability between the treatments. Cross and Carneiro (2006), emphasize that analysis by canonical variables should only be used when, in two or three canonical variables, more than $80 \%$ of the total variation is explained.

Table 3. Eigenvalues obtained from the matrix $\mathrm{HE}^{-1}$ ( $\mathrm{H}$ treatment matrix and $\mathrm{E}$ of the residue)

\begin{tabular}{lll}
\hline Roots & Eigenvalues & Ratio \\
\hline$\lambda_{1}$ & 100.79 & 85.63 \\
$\lambda_{2}$ & 7.65 & 6.50 \\
$\lambda_{3}$ & 6.46 & 5.50 \\
$\lambda_{4}$ & 1.84 & 1.56 \\
$\lambda_{5}$ & 0.95 & 0.81 \\
$\lambda_{1}+\lambda_{2}+\lambda_{3}+\lambda_{4}+\lambda_{5}$ & 117.70 & $100 \%$ \\
\hline
\end{tabular}

The canonical functions obtained for the first two eigenvalues were: $\mathrm{Z} 1=0.662 \mathrm{APL}+0.018 \mathrm{LMR}+266.877$ $\mathrm{DMAP}+187.381 \mathrm{MRS}+0.0787 \mathrm{LA}$ and $\mathrm{Z2}=-2.272 \mathrm{APL}+0.313 \mathrm{LMR}+287.403 \mathrm{DMAP}+274.797 \mathrm{MRS}-$ 1.135 LA. The first canonical function was applied to the data of each experimental plot, generating " $n$ " values of this unique variable $Z$, one of each of the " $n$ " plot of the experiment, obtaining a single $Z$ variable in each plot of the experiment, and then submitted to univariate analysis of variance by applying the Scheffé test at 5\% probability.

\subsection{One-dimensional Analysis of the Variable Z}

It can be observed from the result of this analysis that there were significant differences between the means of the treatments in the different evaluation periods by the Scheffé test (Table 4). The substrates consisting of goat manure and sand were superior to the substrates composed of a babassu palm decomposed stem and the commercial substrate (Tropstrato $\left.\mathrm{HT}^{\circledR}\right)$, the substrate S4 $(25 \%$ sand $+75 \%$ goat manure) being the most suitable / indicated for the development of seedlings of S. lycopersicum, in the four evaluated periods. The advantage of this substrate can be explained by the proportion of sand and goat manure, which resulted in the balance between 
physical and chemical properties, and which provided constant supply of water, oxygen and nutrients to seedlings (Souza et al., 2013).

Table 4. Comparison of the averages generated by the first canonical function between the seven substrates and the four evaluation periods in Solanum lycopersicum seedlings

\begin{tabular}{lllll}
\hline \multirow{2}{*}{$*$ Treatments } & \multicolumn{4}{c}{ Days after the emergency } \\
\cline { 2 - 5 } & 7 & 14 & 21 & 28 \\
\hline S1 & $5.70 \mathrm{bcB}$ & $7.18 \mathrm{dAB}$ & $7.90 \mathrm{dA}$ & $5.42 \mathrm{~dB}$ \\
S2 & $4.45 \mathrm{cA}$ & $6.06 \mathrm{dA}$ & $5.81 \mathrm{dA}$ & $5.11 \mathrm{dA}$ \\
S3 & $4.52 \mathrm{cA}$ & $5.84 \mathrm{dA}$ & $5.90 \mathrm{dA}$ & $5.25 \mathrm{dA}$ \\
S4 & $8.62 \mathrm{aD}$ & $20.64 \mathrm{aC}$ & $32.72 \mathrm{aB}$ & $39.63 \mathrm{aA}$ \\
S5 & $8.00 \mathrm{abC}$ & $17.22 \mathrm{bB}$ & $17.65 \mathrm{bB}$ & $23.97 \mathrm{bA}$ \\
S6 & $6.91 \mathrm{abcB}$ & $10.27 \mathrm{cA}$ & $11.47 \mathrm{cA}$ & $11.27 \mathrm{cA}$ \\
S7 & $4.88 \mathrm{cA}$ & $5.44 \mathrm{dA}$ & $6.47 \mathrm{dA}$ & $6.30 \mathrm{dA}$ \\
\hline
\end{tabular}

Note. Means followed by lower case letters in the columns and upper case in the lines do not differ by the Scheffé test at 5\%. * Treatments: S1-25\% sterilized sand $+75 \%$ decomposed palm stem; S2-50\% sterilized sand $+50 \%$ decomposed palm stem; S3-75\% sterilized sand $+25 \%$ decomposed palm stem; S4-25\% sterile sand + $75 \%$ goat manure; $\mathrm{S} 5-50 \%$ sterilized sand $+50 \%$ goat manure; S6-75\% sterilized sand $+25 \%$ goat manure and S7- commercial substrate (Tropstrato $\mathrm{HT}^{\circledR}$ ).

The density of the substrate constituted by goat manure presented superiority to the substrate decomposed palm stem (Table 1). The higher density of the substrate constituted of decomposed palm stem refers to the existence of smaller porous space related to the physical constitution. This situation is able to prevent the greater use of water and nutrients by the roots of the plants, besides making substrate oxygenation deficient (Almeida \& Sánchez, 2015). The results of porosity associated to substrate density are able to affirm a greater amount of voids in the substrate, as well as verified in the compound by goat manure, which presented better growth response of the seedlings when exposed in the ideal substrate and sand ratio, as well as verified on substrate S4 (Tables 1 and 4). In relation to the nutrient content of the substrates under study, the proportion used between sand and substrate, positively influences the nutritional status of the substrates supplied to the seedlings, which depends on the relationship between sand and substrate in the quantity used (Table 4). Distinguishing in relation to the nutritional content of the substrates, as in the case of the $\mathrm{N}, \mathrm{P}$ and $\mathrm{K}$ average contents, which presented a higher proportion in the substrate composed of goat manure and therefore denote a considerable nutritional improvement of the substrate, favoring the development of S. lycopersicum (Tables 1 and 4). The correlation between the substrates allowed to infer the compound that provides better nutritional conditions to the development of the seedlings, being the compound formed by goat manure able to provide better supply of $\mathrm{N}$ and $\mathrm{K}$, favoring the greater availability of phosphorus to the seedlings (Table 1). The best distribution of these nutrients present in the substrates is fundamental for the development of vegetation in the seedling stage (Almeida \& Sánchez, 2015).

Positive results with the use of goat manure were also observed by Araújo et al. (2010), in the production of Carica papaya seedlings. And also by Notaro et al. (2012), and verified beneficial effects on the production of the grafts of Annona squamosa. In a more refined and precise way, these authors highlighted as a cause for the positive results regarding the use of goat manure, the improvement of the physical, chemical and biological quality of the substrates.

The superiority of the substrates that lead in their formulation goat manure is emphasized in several works, especially when these are compared to the use of other organic materials and even commercial substrates in the soil, as well as Capsicum annum (Barros Júnior et al., 2008), Carica papaya (Araújo et al., 2010), Solanum melongena (Moreira et al., 2010), Annona squamosa (Notaro et al., 2012).

The substrates constituted by the decomposed palm stem were not differentiated from the commercial substrate (Troprasto $\mathrm{HT}^{\circledR}$ ), whose composition includes bark of Pinus, peat and expanded vermiculite, in the different periods of evaluation. The substrate of the decomposed palm tree that provided the best seedlings was the S1 treatment with $25 \%$ sand. However, after 21 days of emergence the seedlings produced in this substrate lost quality. 
The low performance of the seedlings produced with palm-derived stem substrates may be associated with the chemical characteristics of the substrate, which were insufficient for the development of S. lycopersicum seedlings, since the organic matter is remarkably of good physical quality, as well as reported by Moreira et al. (2010), and Souza et al. (2013).

The same trend was observed by Silva-Junior et al. (2014), studying the use of alternative materials in the production of $S$. lycopersicum seedlings under foliar fertilization, which verified that none of the substrate compositions presented sufficient chemical characteristics to promote, without the need for fertilization, the optimal development of the seedlings.

\subsection{Growth Analyzes}

The analysis of the physiological variables followed the same trend of the multidimensional analysis, highlighting the superiority of the substrates that contain in their composition goat manure, when compared to the substrates with formulations of palm tree stem and commercial substrate (Tropstrato $\mathrm{HT}^{\circledR}$ ). S4 treatments, followed by S5 were the substrates that presented the best performance for the variables, growth rate of cultivation (GRC), relative growth rate (RGR), net assimilation rate (NAR) and leaf area ratio (LAR) (Figure 1). 

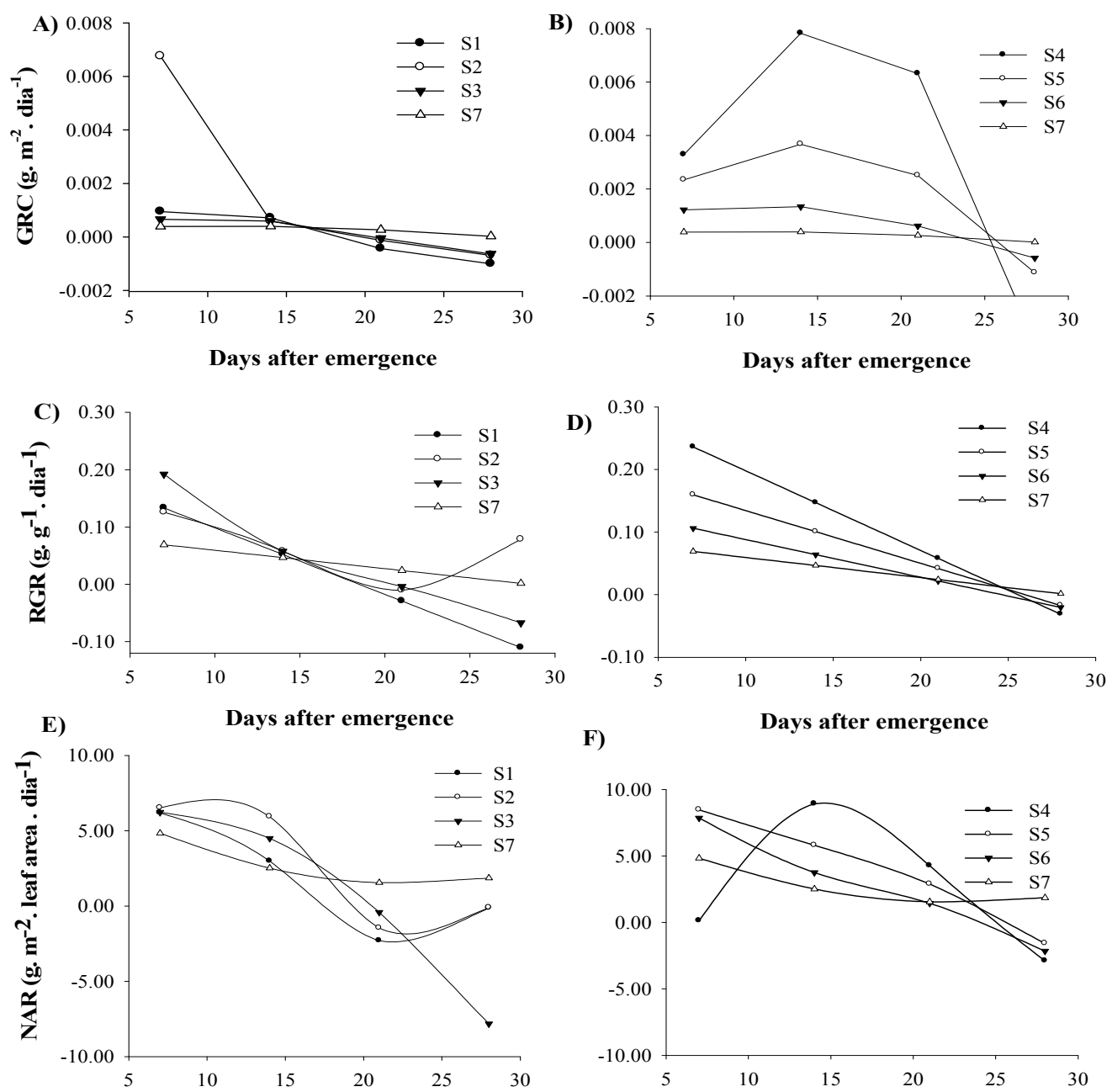

F)
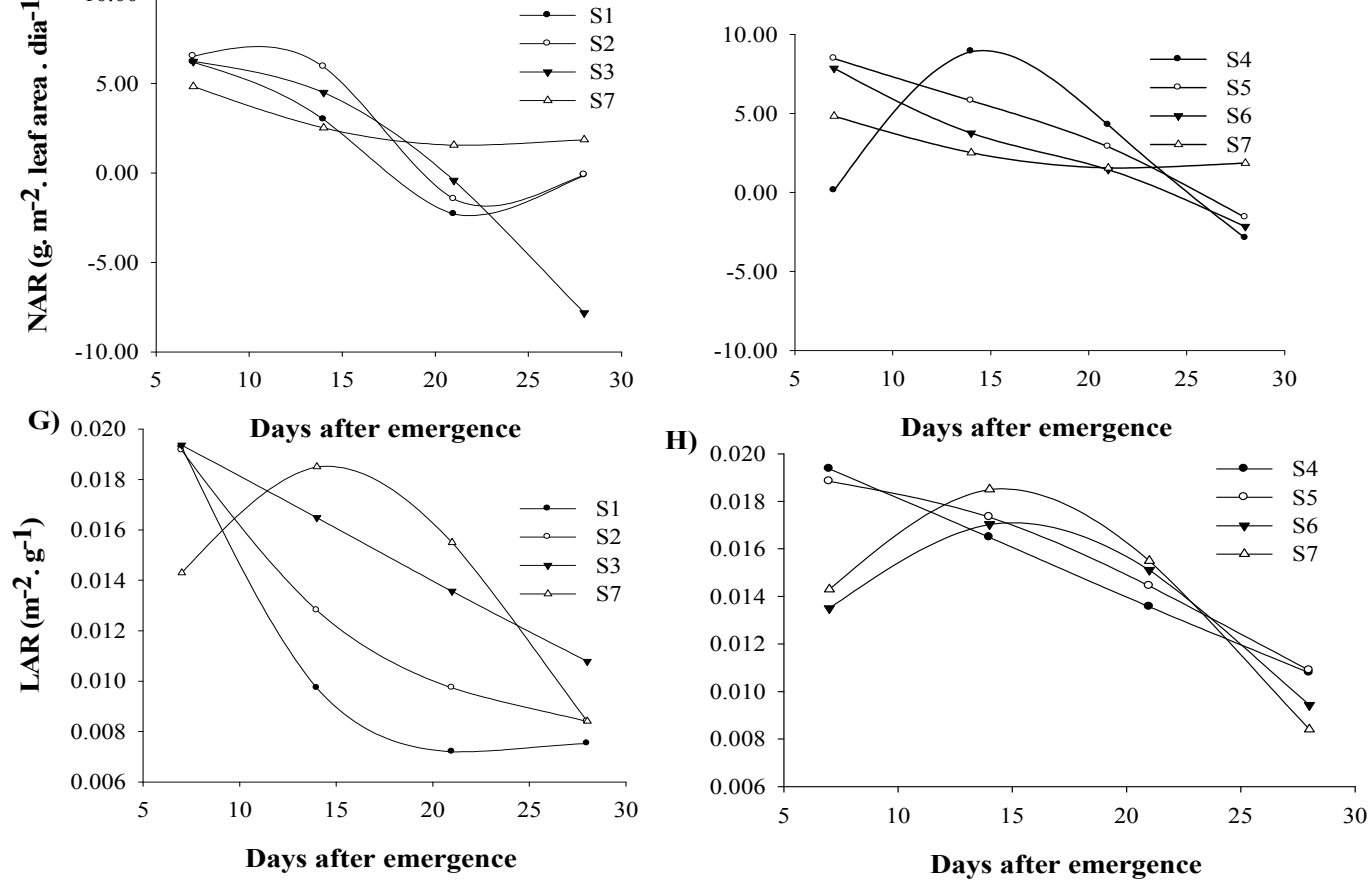

Figure 1. Growth rate of cultivation - GRC (A and B), relative growth rate-RGR (B and D), net assimilatory rate-NAR (E and F) and leaf area ratio-LAR ( $\mathrm{G}$ and $\mathrm{H}$ ) in seedlings of Solanum lycopersicum

Note. The left figures are relative to the substrates that have decomposed stem of palm compared to the commercial substrate (Tropstrato $\mathrm{HT}^{\circledR}$ ) and those of the right the substrates that contain goat manure compared to the commercial substrate (Tropstrato $\mathrm{HT}^{\mathbb{B}}$ ). ${ }^{*}$ Treatments: $\mathrm{S} 1-25 \%$ sterilized sand $+75 \%$ decomposed palm stem; S2-50\% sterilized sand $+50 \%$ decomposed palm stem; S3-75\% sterilized sand $+25 \%$ decomposed palm stem; S4-25\% sterile sand $+75 \%$ goat manure; $\mathrm{S} 5-50 \%$ sterilized sand $+50 \%$ goat manure; $\mathrm{S} 6-75 \%$ sterile sand $+25 \%$ goat manure and $\mathrm{S} 7$-commercial substrate $\left(\right.$ Tropstrato $\mathrm{HT}^{\circledR}$ ).

The formulated substrates of palm decomposed stem compared to the commercial substrate (Tropstrato $\mathrm{HT}^{\circledR}$ ) at seven days post emergence were slightly larger in GRC (Figure 1A), which continues to decrease with time. On the other hand, substrates containing goat manure were much higher than the commercial substrate (Tropstrato 
$\mathrm{HT}^{\circledR}$ ), which reached the maximum point about 15 days after emergence (Figure 1B). As GRC is a derivative of the adjusted equation of total dry matter in relation to time, it is possible to obtain with this variable an idea of average velocity during the growth period (Benincasa, 2004). Thus, the substrate S4 is remarkably the one that provides greater growth the seedlings of $S$. lycopersicum. Organic residues when they pass through the decomposition process that they offer to the organic matter of the soil provide numerous benefits for the forest species, because there is an increase in the moisture retention capacity, it provides nutrients to the substrate and reduces the bulk density, increasing the porosity of the environment (Gonçalves et al., 2000).

Similarly to the results found in this study, Vieira et al. (2016), working with the species Hevea brasiliensis on substrates of soil and cattle manure, were able to promote the greatest growth of seedlings. The use of manure substrate is capable of promoting the growth of high-quality seedlings, as they provide improvements in the physical conditions of the substrate, such as aeration and drainage, as well as providing nutrients (Oliveira et al., 2004; Dias et al., 2009).

In general, the highest values for RGR were observed in the first collection (at seven days), with decreases in the posterior collections (Figure 1C and 1D), with the lowest variations for the commercial substrate (Tropstrato $\mathrm{HT}^{\mathbb{B}}$ ). The decrease in the RGR over time was already expected due to this factor being measured as an efficiency index which represents the ability of the plant to grow. Observing the behavior of the RGR curve in all treatments, it was possible to observe rapid accumulation of dry matter at the beginning of the development of $S$. lycopersicum plants, decreasing with time.

With the increase of the dry mass accumulated by the plants, there is an increase in the need of photoassimilates to keep the already formed structures in operation, thus reducing plant growth (Ferrari et al., 2008). This fact can be explained by the increase of the respiratory activity and by the self-shading that increases with the age of the plant and still indicate the approximation of culture senescence, allowing the net assimilation to be negative (Barreiro et al., 2006; Cometti et al., 2008). Reduction in RGR values were also found by Ludwig et al. (2010) in studies with different organic substrates in the culture of Gerbera jamesonii during the development of the crop.

The NAR can be represented by the balance that occurs between the material produced in the photosynthesis and the material lost during the respiratory phase, this balance is capable of expressing the leaf efficiency in dry mass production and the estimation of liquid photosynthesis (Benincasa, 2004).

Regardless of the substratum that $S$. lycopersicum plants developed NAR tended to decrease during the development of the seedlings (Figures 1E and 1F), except for the plants of the substrate S4, in which the behavior of the upward curve reached a point of maximum net assimilation around 15 days after the emergency. The increase in NAR in the first 15 days after the emergence of the plants that developed in the S4 substrate can be explained by the absence of self-shading in the initial stages of the plant, which resulted in greater assimilation of $\mathrm{CO}_{2}$, in response to the photosynthetic rate observed in GRC (Figure 1B).

According to Cairo et al. (2008), the NAR commonly decreases over time, this behavior can be explained by the increase of the leaf area along the plant cycle causing self-shading. This statement is consistent with the record of Lopes et al. (2011), which attributed the decrease of NAR in S. lycopersicum cultivated under different soil cover, to the increase of the leaf area, responsible for the self-shading of the leaves, which led to a decrease in liquid photosynthesis levels. Likewise, Ludwig et al. (2010) in studies with different organic substrates in the Gerbera jamesonii crop showed to decrease in the liquid photosynthesis during the growth of the crop, which according to the authors this reduction is associated with the self-representation acquired by the plant during the growth phase, caused by the overlapping of the leaves, and consequently, reduction of photosynthetic efficiency and increase of respiratory losses.

The LAR had an upward growth for the substrates S6 and S7 until the 15 days after the emergency. For the other substrates the LAR decreased during the development of the plants (Figures $1 \mathrm{G}$ and $1 \mathrm{H}$ ). The behavior noted for substrates S6 and S7 may be associated with GRC as it remains practically unchanged (Figure 1B). At the beginning of the evaluation period the LAR was higher, this process occurs because it is the period that the plant converts greater energy to the photosynthetic production necessary for leaf expansion and light capture, after this decreasing the values along the crop cycle, due interference of the upper leaves on the inferior ones, reducing the photosynthesis due to the reduction of the leaf area of the plant.

According to Benincasa (2004), the LAR expresses to the foliar area useful for photosynthesis, being the relationship between the leaf area responsible for the interception of light energy and $\mathrm{CO}_{2}$ and the total dry mass, resulting from photosynthesis. Thus, for the treatments in which the LAR decreases linearly throughout the development, there was an increase of the interference of the superior leaves on the inferior ones, indicating growth. The decrease in LAR throughout development is commonly reported in the literature, as reported by 
Barreiro et al. (2006), evaluating plants of Ocimum basilicum treated with plant regulators. Ludwig et al. (2010) in studies with different organic substrates in Gerbera jamesonii also found a decrease in LAR due to the development of the culture, mainly with the beginning of the reproductive phase.

The reduction of LAR can be explained by the greater efficiency of the leaf in converting light energy and carbon dioxide to dry mass, as part of the reproductive cycle of the species. In this way, the analysis of growth is an important technique used in the evaluation of the adaptations of the plant under different culture conditions (Ludwig et al., 2010).

\section{Conclusion}

The use of the multivariate method in association with the growth analysis was very informative and advantageous due to the greater discriminant capacity, besides the description of the relative superiority of the substrates by means of the technique of canonical variables, the alternative substrate formed by the mixture of goat manure in the proportion of $25 \%$ sterile sand $+75 \%$ goat manure, is the best option for the production of $S$. lycopersicum seedlings in terms of the production of more vigorous seedlings.

\section{Acknowledgements}

The authors acknowledge the support of Foundation for the Support of Research Scientific, and Technological Development of the state of Maranhão-FAPEMA.

\section{References}

Albano, F. G., Marques, A. S., \& Cavalcante, I. H. L. (2014). Substrato alternativo para produção de mudas de mamoeiro formosa (cv. Caliman). Cientifica, 42, 388-395. https://doi.org/10.15361/1984-5529.2014v42 n4p388-395

Alencar, F. H. H., Silva, W. A., Pereira Júnior, E. B., Damasceno, M. M., \& Souto, J. S. (2008). Crescimento inicial de plantas de sábia em Latossolo degradado do Cariri Cearense sob efeito de estercos e fertilizantes químicos. Revista Verde, 3, 1-5.

Almeida, R. O. P. O., \& Sánchez, L. E. (2015). Indicadores da Qualidade do Substrato para Monitoramento de Áreas de Mineração Revegetadas. Floresta e Ambiente, 22, 153-163. https://doi.org/10.1590/2179-8087. 072714

Alvares, C. A., Stape, J. L., Sentelhas, P. C., \& Gonçalves, J. L. M. (2013). Sparovek, G. Köppen's climate classification map for Brazil. Meteorologische Zeitschrif, 22, 711-728. https://doi.org/10.1127/0941-2948/ 2013/0507

Araújo, W. B. M., Alencar, R. D., Mendonça, V., Medeiros, E. V., Andrade, R. C., \& Araújo, R. R. (2010). Esterco caprino na composição de substratos para formação de mudas de mamoeiro. Ciência Agrotecnologia, 34, 68-73. https://doi.org/10.1590/S1413-70542010000100008

Barreiro, A. P., Zucareli, V., Ono, E. O., \& Rodrigues, J. D. (2006). Análise de crescimento de plantas de manjericão tratadas com reguladores vegetais. Bragantia, 65, 563-567. https://doi.org/10.1590/S0006-87 052006000400005

Barros Júnior, A. P., Neto, F. B., Silveira, L. M., Câmara, M. J. T., \& Barros, N. M. S. (2008). Utilização de compostos orgânicos no crescimento de mudas de pimentão. Revista Caatinga, 21, 126-130.

Benincasa, M. M. P. (2004). Análise de crescimento de plantas: noções básicas (p. 42). Jaboticabal: FUNEP.

Bezerra Neto, F., Gomes, E. G., Nunes, G. H. S., \& Oliveira, E. Q. (2007). Desempenho de sistemas consorciados de cenoura e alface avaliados através de métodos uni e multivariados. Horticultura Brasileira, 25, 514-520. https://doi.org/10.1590/S0102-05362007000400005

Cabral, P. D. S., Soares, T. C. B., Lima, A. B. P., Alves, D. S., \& Nunes, J. A. (2011). Diversidade genética de acessos de feijão comum por caracteres agronômicos. Revista Ciência Agronômica, 42, 898-905. https://doi.org/10.1590/S1806-66902011000400011

Cairo, P. A. R., Oliveira, L. E. M., \& Mesquita, A. C. (2008). Análise de crescimento de plantas. Vitória da Conquista: Edições UESB.

Castoldi, R., Gomes, R. F., Cahrlo, H. C. O., Melo, D. M., \& Braz, L. T. (2014). Performance of cucumber hybrids cultivated in coconut fiber and soil. Horticultura Brasileira, 32, 86-90. https://doi.org/10.1590/ S0102-0536 2014000100014 
Cometti, N. N., Matias, G. C. S., Zonta, E., Mary, W., \& Fernandes, M. S. (2008). Efeito da concentração da solução nutritiva no crescimento da alface em cultivo hidropônico-sistema NFT. Horticultura Brasileira, 26, 262-267. https://doi.org/10.1590/S0102-05362008000200027

Costa, E., Santo, T. L. E., Silva, A. P., Silva, L. E., Oliveira, L. C., Benett, C. G. S., \& Benett, K. S. S. (2015). Ambientes e substratos na formação de mudas e produção de frutos de cultivares de tomate cereja. Horticultura Brasileira, 33, 110-118. https://doi.org/10.1590/S0102-053620150000100018

Costa, L. M., Andrade, J. W. S., Rocha, A. C., Souza, L. P., \& Flávio Neto, J. (2009). Avaliação de substratos para o cultivo de pepino (Cucumis sativus L.). Global Science and Technology, 2, 21-26.

Cruz, C. D., \& Carneiro, P. C. S. (2006). Modelos biométricos aplicados ao melhoramento genético (2nd ed.). Viçosa: UFV.

Dias, R., Melo, B., Rufino, M. A., Silveira, D. L., Morais, T. P., \& Santana, D. G. (2009). Fontes e proporção de material orgânico para a produção de mudas de cafeeiro em tubetes. Ciência e Agrotecnologia, 33, $758-764$. https://doi.org/10.1590/S1413-70542009000100021

Ferrari, T. B., Ferreira, G., Zucareli, V., \& Boaro, C. S. F. (2008). Efeito de reguladores vegetais nos índices da análise de crescimento de plântulas de maracujazeiro-doce (Passiflora alata Curtis). Biotemas, $21,45-51$. https://doi.org/10.5007/2175-7925.2008v21n3p45

Gaspar, J. C., Furtado, M. B., Silva, W. J. S., Reis, I. S., Machado, N. A. F., Farias, M. F., ... Silva-Matos, R. R. S. (2018). Impacts of Residual Phosphorus on the Production of Cowpea in the Cerrado Region. American Journal of Plant Sciences, 9, 645-658. https://doi.org/10.4236/ajps.2018.94051

Gonçalves, J. L. M., Santarelli, E. G., Moraes Neto, S. P., \& Manara, M. P. (2000). Produção de mudas de espécies nativas: Substrato, nutrição, sombreamento e fertilização. In J. L. M. Gonçalves, \& V. Benedetti, (Eds.). Nutrição e fertilização florestal (pp. 309-350). Piracicaba: IPEF.

Gonçalves, L. S. A., Rodrigues, R., Amaral Júnior, A. T., Karasawa, M., \& Sudré, C. P. (2009). Heirloom tomato gene bank: Assessing genetic divergence based on morphological, agronomic and molecular data using Ward-modified location model. Genetics and Molecular Research, 8, 364-374. https://doi.org/10.4238/ vol8-gmr549

IBGE (Instituto Brasileiro de Geografia e Estatística). (2017). Levantamento Sistemático da Produção Agrícola-Dezembro de 2017. Retrieved from https://sidra.ibge.gov.br/tabela/6588

IBGE (Instituto Brasileiro de Geografia e Estatística). (2018). Levantamento Sistemático da Produção Agrícola-Junho de 2018. Retrieved from https://sidra.ibge.gov.br/pesquisa/lspa/tabelas

Lima, R. D. L. S., Severino, L. S., Ferreira, G. B., Sofiatti, V., Sampaio, L. R., \& Macêdo-Beltrão, N. E. (2011). Casca de mamona associada a quatro fontes de matéria orgânica para a produção de mudas de pinhão-manso. Ceres, 58, 232-237. https://doi.org/10.1590/S0034-737X2011000200015

Lopes, W. A. R., Negreiros, M. Z., Dombroski, J. L. D., Rodrigues, G. S. O., Soares, A. M., \& Araújo, A. P. (2011). Análise do crescimento de tomate 'SM-16' cultivado sob diferentes coberturas de solo. Horticultura Brasileira, 29, 554-561. https://doi.org/10.1590/S0102-05362011000400019

Ludwig, F., Guerrero, A. C., Fernandes, D. M., \& Villas Boas, R. L. (2010). Análise de crescimento de gérbera de vaso conduzida em diferentes substratos. Horticultura Brasileira, 28, 70-74. https://doi.org/10.1590/ S0102-05362010000100013

Maeda, S., Dedecek. R. A., Agostini, R. B., Andrade, G. C. A., \& Silva, H. D. (2007). Caracterização de substratos para produção de mudasde espécies florestais elaboradas a partir de resíduos orgânicos. Pesquisa Florestal Brasileira, 54, 97-104.

Melo, D. M., Castoldi, R., Charlo, H. C. O., Galatti, F. S., \& Braz, L. T. (2012). Produção e qualidade de melão rendilhado sob diferentes substratos em cultivo protegido. Revista Caatinga, 25, 58-66.

Moreira, M. A., Dantas, F. M., Bianchini, F. G., \& Viégas, P. R. A. (2010). Produção de mudas de berinjela com uso de pó de coco. Revista Brasileira de Produtos Agroindustriais, 12, 163-170. https://doi.org/10.15871 /1517-8595/rbpa.v12n2p163-170

Notaro, K. A., Medeiros, E. V., Silva, A. O., Silva, M. M., Souza, B. M., \& Duda, G. P. (2012). População microbiana rizosférica, disponibilidade de nutrientes e crescimento de pinheira, em substratos com resíduos orgânicos. Brazilian Journal of Agricultural Sciences, 7, 770-776. https://doi.org/10.5039/agraria.v7isa2013 
Oliveira Neto, E. D., Andrade, H. A. F., Oliveira, A. R. F., Morais, L. F., Santos, L. R., Pontes, M. S. F., ... Matos, R. R. S. S. (2018). Vegetative propagation of pomegranate 'wonderful' in substrates of decomposed babassu stem. Asian Academic Research Journal of Multidisciplinary, 5, 167-179.

Oliveira, L. C., Costa, E., Oliveira Sobrinho, M. F., Binotti, F. F. S., Maruyama, W. I., \& Alves, A. C. (2014). Esterco bovino e fibra de coco na formação de mudas de baruzeiro. Revista de Agricultura Neotropical, 1, $42-51$.

Pimentel-Gomes, F., \& Garcia, C. H. (2002). Estatística aplicada a experimentos agronômicos e florestais: Exposição com exemplos e orientações para uso de aplicativos. Piracicaba: Fealq.

Portes, T. A., \& Castro Jr., L. G. (1991). Análise de crescimento de plantas: Um programa computacional auxiliar. Revista Brasileira de Fisiologia Vegetal, 3, 53-56.

R Development Core Team. (2018). R: The R Project for Statistical Computing, 2018. Retrieved from https://www.r-project.org

Royston, J. P. (1982). An extension of Shapiro and Wilk's W test for normality to large samples. Applied Statistics, 31, 115-124. https://doi.org/10.2307/2347973

Sas Institute. (2002). Statistical analysis system user's guide (Version 9.0). Cary: SAS Institute.

Schneider, C. A., Rasband, W. S., \& Eliceiri, K. W. (2012). Nih Image to ImageJ: 25 years of image analysis. Nature Methods, 9, 671-675. https://doi.org/10.1038/nmeth.2089

Silva Júnior, J. V., Cavalcante, M. Z. B., Brito, L. P. S., Avelino, R. C., \& Cavalcante, I. H. L. (2014). Aproveitamento de materiais alternativos na produção de mudas de tomateiro sob adubação foliar. Revista Ciência Agronômica, 45, 528-536. https://doi.org/10.1590/S1806-66902014000300013

Sousa, W. C., Nóbrega, R. S. A., Nóbrega, J. C. A., Brito, D. R. S., \& Moreira, F. S. (2013). Fontes de nitrogênio e caule decomposto de Mauritia flexuosana nodulação e crescimento de enterolobium contortsiliquum. Revista árvore, 37, 969-979. https://doi.org/10.1590/S0100-67622013000500019

Souza, E. G. F., Barros Junior, A. P., Silveira, L. M., Santos, M. G., \& Silva, E. F. (2013). Emergência e desenvolvimento de mudas de tomate IPA 6 em substratos, contendo esterco ovino. Revista Ceres, 60, 902-907. https://doi.org/10.1590/S0034-737X2013000600020

Vieira, N. C. S., Maruyama, W. I., Costa, E., Dias, P. M., \& Pereira, A. C. (2016). Clones, substrates and environments for seedlings of rubber tree rootstocks. Engenharia Agricola, 36, 749-759. https://doi.org/ 10.1590/1809-4430-Eng.Agric.v36n5p749-759/2016

\section{Copyrights}

Copyright for this article is retained by the author(s), with first publication rights granted to the journal.

This is an open-access article distributed under the terms and conditions of the Creative Commons Attribution license (http://creativecommons.org/licenses/by/4.0/). 